Irawan, Denny Hermawan/Ta'dib: Jurnal Pendidikan Islam, Vol. 8 No. 2 (2019) 626-631

ISSN 1411-8173 | E-ISSN 2528-5092

https://ejournal.unisba.ac.id/index.php/tadib/article/view/5254

\title{
KONSEPTUAL MODEL PENDIDIKAN DEMOKRATIS PERSPEKTIF PENDIDIKAN ISLAM
}

\author{
Irawan $^{1}$, Denny Hermawan ${ }^{2}$ \\ 1,2 Program Studi Pendidikan Agama Islam Universitas Islam Syekh Yusuf, Indonesia. \\ Email: 1irawan@unis.ac.id, 2dhermawan@unis.ac.id.
}

DOI: $10.29313 /$ tjpi.v8i2.5254

Accepted: October 18th, 2019. Approved: November 25th, 2019. Published: November 25th, 2019

\begin{abstract}
Democracy about education in which many problems often occur, one of which is a problem that often occurs in the world of education according to the observations of researchers, such as schools, especially teachers often become a reference of many things that are not desired by the community. When children depend on watching television, it is the school that is targeted because it is considered not to provide maximum media education. When brawls often occur, it is the school that is highlighted the most because schools lack instill education in values. When people do not know much about technology, it is also the school that is the focus because of inattention to the times, and there are still many other examples of problems. The purpose of this study is to find out what is a democratic concept in Islam and to explain democratic education according to Islam. The research method used is a grounded theory method that uses data from materials that are a library (library research), where the author reads and studies books or literature relating to the problem under study. The principles of Islamic democracy towards Islamic education are: There is freedom for educators and students, which freedom bere includes: freedom of work, freedom to develop potential and freedom of opinion. Similarities with students in Islamic education. Because Islam provides equal opportunities for all students to get an education or study. Respect for the dignity of individuals in Islamic education.
\end{abstract}

Keywords: Democracy; Discussion; Education; Value.

\begin{abstract}
Abstrak
Demokrasi mengenai pendidikan yang mana banyak permasalahan yang sering terjadi salah satunya adalah masalah yang sering terjadi dalam dunia pendidikan menurut hasil pengamatan peneliti, seperti: sekolah terutama guru sering menjadi rujukan dari banyak hal yang tidak diinginkan masyarakat. Ketika anak-anak ketergantungan menonton televisi, sekolablah yang yang menjadi sasaran karena dianggap tidak memberikan pendidikan media yang maksimal. Ketika sering terjadi tawuran, sekolahlah yang paling disorot karena sekolah kurang menanamkan pendidikan nilai. Ketika masyarakat tidak mengenal jaub teknologi, sekolablah juga yang menjadi tumpuan karena kurang perhatian terhadap perkembangan zaman, dan masib banyak contoh masalabmasalah yang lainnya. Tujuan dari penelitian ini adalah untuk mengetahui konsep demokratis dalam Islam dan untuk menjelaskan pendidikan demokratis menurut Islam. Metode penelitian yang digunakan adalah metode teori dasar yang menggunakan data dari bahan-bahan yaitu bersifat kepustakaan (library research), dimana penulis membaca dan mempelajari buku-buku atau literatur yang berhubungan dengan permasalahan yang diteliti. Prinsip demokratis dalam Pendidikan Islam yaitu: Adanya kebebasan bagi pendidik dan peserta didik, yang mana kebebasan di sini meliputi: kebebasan berkarya, kebebasan mengembangkan potensi dan kebebasan berpendapat. Persamaan terhadap peserta didik dalam pendidikan Islam. Karena, Islam memberikan kesempatan yang sama bagi semua peserta didik untuk mendapatkan pendidikan atau belajar. Penghormatan akan martabat individu dalam pendidikan Islam.
\end{abstract}

Kata Kunci: Demokerasi; Musyawarh; Pendidikan; Nilai. 


\section{PENDAHULUAN}

Banyak permasalahan yang sering terjadi salah satunya adalah masalah yang sering terjadi dalam dunia pendidikan menurut hasil pengamatan peneliti, seperti: sekolah terutama guru sering menjadi rujukan dari banyak hal yang tidak diinginkan masyarakat. Ketika anak-anak ketergantungan menonton televisi, sekolahlah yang yang menjadi sasaran karena dianggap tidak memberikan pendidikan media yang maksimal. Ketika sering terjadi tawuran, sekolahlah yang paling disorot karena sekolah kurang menanamkan pendidikan nilai. Ketika masyarakat tidak mengenal jauh teknologi, sekolahlah juga yang menjadi tumpuan karena kurang perhatian terhadap perkembangan zaman.

Masih banyak lagi kesalahan yang sering ditimpakan kepada sekolah. Padahal bukan hanya sekolah yang bertanggung jawab terhadap apa yang terjadi di dunia pendidikan saat ini. Semua anggota mempunyai atau seharusnya menyadari bahwa ini adalah tanggung jawab bersama. Maka pendidikan bisa dijamin dan memiliki masa depan yang baik, asalkan tanggung jawab itu tidak di berikan sepenuhnya kepada sekolah. Namun, perlu adanya sinergitas antara sekolah, keluarga dan masyarakat sebagai tripusat pendidikan yang harus saling berpengaruh satu sama lainnya (Tirtarahardja \& Sulo, 2008).

Konsep pendidikan yang demokratis adalah pendidikan yang memberikan kesempatan yang sama kepada setiap anak untuk mendapatkan pendidikan di sekolah sesuai dengan kemampuannya (Ubaedillah \& Rozak, 2014). Pengertian demokratis di sini mencakup arti baik secara horizontal maupun vertikal. Jadi demokrasi pendidikan di sini adalah proses pendidikan yang menghargai potensi (pembawaan), persamaan dan kebebasan peserta didik dalam mengembangkan dan mengaktualisasikan segala potensi dirinya secara optimal. Tanpa memandang atau membeda-bedakan suku, agama maupun budaya.

Tujuan penelitian ini adalah untuk mengetahui apakah konsep demokratis dalam Islam dan untuk menjelaskan pendidikan demokratis dalam perspektif Islam. Karena Islam sendiripun sebetulnya telah mengajarkan kepada kita bahwa kita sebagai manusia yang hidup bermasyarakat, berbangsa dan bernegara harus senantiasa saling menghargai, bertoleransi tanpa membeda bedakan suku, ras, agama dan lain-lainnya, sehingga dapat terbentuklah pribadi-pribadi muslim yang baik, adil dan berakhlak mulia.

Kata demokrasi berasal dari demos dan cratos yang artinya pemerintahan rakyat. Rakyatlah yang berkuasa yang menentukan keinginan mereka, sebagai lawan dari dictator dan tirani. Dengan demikian hakikat demokrasi adalah adanya keadilan, persamaan, kesetaraan, kebebasan, sehingga menghilangkan penjajahan manusia atas manusia, pemaksaan dan pemerkosaan hak asasi manusia. Timbulnya hal ini tidak lain adalah respon terhadap ketidakadilan yang telah terjadi, di mana terjadinya penjajahan manusia atas manusia (Daulay, 2014). Keberhasilan demokrasi ditunjukan oleh sejauh mana demokrasi sebagai prinsip dan acuan hidup bersama antar warga negara dan antar warga negara dengan negara dijalankan dan dipatuhi oleh kedua belah pihak (Ubaedillah \& Rozak, 2014). Bukan hanya itu keberadaan demokrasi pendidikan Islam, tentu saja tidak dapat dilepaskan dari sejarah lahirnya demokrasi dalam ajaran Islam dan demokrasi secara umum. Demokrasi dalam ajaran Islam secara prinsip telah diterapkan oleh $\mathrm{Nabi}$ Muhammad saw. yang dikenal dengan istilah "musyawarah". Kata demokrasi memang tidak ada terdapat di dalam AlQur'an dan Hadis, karena kata demokrasi berasal dari Barat atau Eropa yang masuk ke peradaban Islam (Ramayulis, 2013).

Demokrasi yang ditegakan adalah untuk mewujudkan civil society dengan menjadikan demokrasi sebagai pandangan 
hidup (way of life). Sekalipun demokrasi berasal dari Barat, namun prinsip-prinsip demokrasi tersebut menurut Nurcholish Majid telah ada dalam tubuh Islam. Oleh sebab itu, pandangan hidup demokratis ialah cerminan sikap jiwa dan semangat peradaban yang telah menjadi pandangan hidup dalam kehidupan sehari-hari (Yasmadi, 2002).

\section{METODOLOGI PENELITIAN}

Penelitian ini menggunakan metode teori dasar yang menggunakan data dari bahan-bahan yaitu bersifat kepustakaan (library research), dimana penulis membaca dan mempelajari buku-buku atau literatur yang berhubungan dengan permasalahan yang diteliti. Sumber utama yang digunakan dalam penelitian ini adalah Al-Qur'an dan beberapa tafsir yang berkaitan dengan pendidikan demokratis. Sedangkan sumber data sekundernya, yaitu buku-buku, jurnal dan lain-lain yang membahas mengenai permasalahan judul yang diteliti. Langkah yang digunakan dalam pengolahan data dalam penelitian ini adalah langkah deskriptif, yaitu langkah yang menggambarkan atau menguraikan suatu hal tentang permasalahan yang diteliti.

\section{HASIL DAN PEMBAHASAN}

\section{Definisi Demokrasi}

Secara etimologis kata demokrasi berasal dari bahasa Yunani (demokratia). Terdiri dari dua bagian, demos artinya rakyat dan kratos atau kratein yang berarti kekuasaan. Jadi konsep dasar demokrasi itu adalah kekuasaan rakyat, atau kekuasaan milik rakyat, atau government of rule by the people. Jadi, istilah demokrasi secara singkat diartikan sebagai, suatu kekuasaan politik yang kedaulatan pemerintahan berasal dari rakyat baik secara langsung maupun melalui perwakilan (Samudin, 2013).

\section{Demokrasi dalam Islam}

Secara etimologis, Islam tidak mengenal istilah demokrasi. Islam hanya mengenal istilah musyawarah sebagai fondasi utama dalam kehidupan sosial. Beranjak dari konsepsi musyawarah inilah Islam memperkenalkan gagasan demokrasi, yakni gagasan yang mengharuskan seluruh proses politik melandaskan diri pada partisipasi, kebebasan, dan persamaan (Musa, 2014). Umat Islam telah bersepakat, bahwa salah satu prinsip ajaran Islam tentang kehidupan bermasyarakat dan bernegara adalah prinsip musyawarah (syûrâ). Musyawarah atau syura adalah sesuatu yang sangat penting guna menciptakan peraturan di dalam masyarakat mana pun. Dan setiap negara maju yang menginginkan keamanan, ketentraman, kebahagiaan, dan kesuksesan bagi rakyatnya, tetap memegang prinsip musawarah (Ilyas, 2012).

$$
\text { Jadi setidaknya menurut }
$$

(Ubaedillah \& Rozak, 2014) menyatakan bahwa, terdapat tiga pandangan tentang Islam dan Demokrasi: Pertama, Islam dan demokrasi adalah dua sistem politik yang berbeda. Islam tidak bisa disubordinatkan dengan demokrasi karena Islam merupakan sistem politik yang mandiri (self- sufficient). Dalam bahasa politik muslim, Islam sebagai agama yang sempurna tidak saja mengatur persoalan keimanan (akidah) dan ibadah, melainkan mengatur segala aspek kehidupan umat manusia termasuk aspek kehidupan bernegara. Pandangan ini didukung oleh kalangan pemikir muslim seperti Sayyid Qutb dan Thabathabi. Hubungan Islam dan demokrasi bersifat saling menguntungkan secara eksklusif (mutually exclusve). Bagi penganut demokrasi sebagai satu-satunya sistem terbaik yang tersedia saat ini, Islam dipandang sebagai sistem politik alternatif terhadap demokrasi. Sebaliknya, bagi pandangan Islam sebagai sistem yang lengkap. Islam dan demokrasi adalah sistem yang berbeda, karena itu demokrasi sebagai konsep barat tidak tepat dijadikan sebagai acuan dalam 
hidup bermasyarakat, berbangsa, dan bernegara. Dalam masyarakat muslim, Islam tidak bisa dipadukan dengan demokrasi.

Kedua, kelompok kedua ini menyetujui adanya prinsip-prinsip demokrasi dalam Islam. Tetapi, mengakui adanya perbedaan antara Islam dan demokrasi. Bagi kelompok ini, Islam merupakan sistem politik demokratis kalau demokratis didefinisikan secara subtantif, yakni kedaulatan di tangan rakyat dan negara merupakan terjemahan dari kedaulatan rakyat ini. Dengan demikian, dalam pandangan kelompok ini, demokrasi adalah konsep yang sejalan dengan Islam setelah diadakan penyesuaian penafsiran terhadap konsep demokrasi itu sendiri. Di antara tokoh dari kelompok ini adalah AlMaududi dan Moh. Natsir.

Ketiga, Islam adalah sistem nilai yang membenarkan dan mendukung sistem politik demokrasi seperti yang dipraktikan negara-negara maju. Islam di dalam dirinya demokratis tidak hanya karena prinsip syura (musyawarah), tetapi karena adanya konsep ijtihad dan ijma (konsensus). Di antara tokoh muslim yang mendukung pandangan ini yaitu Fahmi Huwaidi, M. Husain Haekal, dan Muhammad Abduh. Di Indonesia diwakili oleh Nurcholis Majid, Abdurrahman Wahid, Amin Rais, dan Ahmad Syafi'i Ma'arif (Ubaedillah \& Rozak, 2014).

\section{Demokrasi dalam Pendidikan Islam}

Demokrasi dan pendidikan mempunyai hubungan yang saling menunjang, karena pendidikan yang sifatnya demokratis akan menempatkan anak sebagai pusat perhatian. Melalui pendidikan anak-anak ditempatkan sebagai manusia yang dimanusiakan. Pendidikan hanya memberikan layanan yang kondusif bagi pertumbuhan dan perkembangan optimal anak. pendidikan yang demokrasi adalah pendidikan yang memberikan kesempatan yang lama kepada setiap anak (peserta didik) mencapai tingkat pendidikan sekolah yang setinggi-tingginya sesuai dengan kemampuannya. Demokrasi pendidikan, adalah pengajaran pendidikan yang semua anggota masyarakat mendapatkan pendidikan dan pengajaran yang adil.

Sebagaimana amanat UUD 1945 mengatakan bahwa pemerintah akan mewujudkan suatu sistem pendidikan yang mencerdaskan rakyat. Pendidikan yang mencerdaskan rakyat adalah pendidikan yang membawa warga negaranya sebagai anggota masyarakat demokratis. Proses pendidikan yang demikian bukanlah proses indoktrinasi tetapi menyadarkan rakyat akan hak-haknya dan memberikan kemampuan pada rakyat untuk secara bersama-sama mewujudkan keadilan dan kemakmuran bersama (Tilaar, 2012). Jadi siswa di sekolah harus merasakan bahwa sekolah bagi mereka sungguh merupakan tempat yang akan menggali potensi yang dimiliki. Dengan kondisi yang tidak diskriminatif dan berkeadilan, anak yang berasal dari keluarga miskin pun berhak mendapat perlakuan yang sama dalam memperoleh pendidikan. Dan tidak heran ketika muncul kesadaran dan daya kritis tentang keberadaan Rintisan Sekolah Bertarif Internasional (RSBI) yang akhirakhir ini dipertanyakan dan diklm untuk ditiadakan. Karena itu, untuk mendidik warga negara yang baik, pendidikan demokratis mutlak dibutuhkan.

Prinsip demokrasi pendidikan Islam dijiwai oleh prinsip demokrasi dalam Islam, atau dengan kata lain demokrasi pendidikan Islam merupakan implementasi prinsip demokrasi Islam terhadap pendidikan Islam. pendidikan Islam menurut Ramayulus dapat dibagi adalah sebagai berikut:

1. Kebebasan bagi pendidik dan peserta didik.

Kebebasan disini meliputi: kebebasan berkarya, kebebasan 
mengembangkan potensi dan kebebasan berpendapat.

2. Persamaan terhadap peserta didik dalam pendidikan Islam.

Karena, Islam memberikan kesempatan yang sama bagi semua peserta didik untuk mendapatkan pendidikan atau belajar (Ramayulis, 2013).

Peserta didik yang masuk di lembaga pendidikan tidak ada perbedaan derajat atau martabat, karena penyelenggaraan pendidikan dilaksanakan dalam suatu ruangan dengan tujuan untuk memperoleh pengetahuan dan pendidikan. Pendidik harus mengajar anak orang yang tidak mampu dengan yang mampu secara bersama atas dasar penyediaan kesempatan belajar yang sama bagi semua peserta didik. Sehingga penddik harus mampu memberikan kesempatan yang sama kepada semua peserta didik untuk mendapatkan pendidikan. Bagi peserta didik yang kurang aspiratif dalam belajar diberikan latihanlatihan remedial secara khusus, sedangkan yang cerdas diberikan tambahan (pengajaran) yang belum dipelajarinya.

\section{Implementasi Nilai Demokrasi dalam Pendidikan Islam}

Proses pembelajaran harus dilandasi oleh nilai-nilai demokrasi yaitu dengan penghargaan terhadap kemampuan peserta didik, menerapkan persamaan kesempatan dan memperhatikan keragaman peserta didik. proses pendidikan demokratis ditujukan kepada pengembangan pribadi yang mandiri dan bertanggung jawab. Sebagaimana dapat dilihat dalam demokrasi itu sendri bahwa demokrasi dalam praktiknya di mana pun di muka bumi selalu menuntut tiga atau empat syarat yang saling melengkapi: rasa tanggung jawab, lapang dada, rela menerima kekalahan secara sportif, dan tidak membiarkan kesadaran membeku (Maarif, 2015).

Jadi pendidik hendaknya memposisikan peserta didiknya sebagai insan yang harus dihargai kemampuannya dan diberi kesempatan untuk mengembangkan kemampuannya tersebut. Oleh sebab itu dalam proses pembelajaran, harus dihindari suasana belajar yang kaku, penuh dengan ketegangan, syarat dengan perintah dan instruksi yang membuat peserta didik menjadi pasif dan tidak bergairah, cepat bosan dan mengalami kelelahan. Bahkan sebagai aplikasi dari prinsip demokrasi, pendidikan diselenggarakan secara gratis, tidak terikat pada batas waktu tertentu, ijazah, atau nilai angka-angka dalam ujian ataupun peraturan-peraturan khusus dalam pemerintahan siswa. Sebaliknya, bila seseorang berkeinginan kuat untuk belajar, cinta kepada ilmu ataupun melakukan penelitian, pinta untuk belaar terbuka luas baginya. Secara esensial, demokrasi pendidikan merupakan suatu gambaran ideal yang akan terus diperjuangkan dan disempurnakan.

\section{KESIMPULAN}

Konsep demokrasi dalam Islam adalah bahwa dalam Islam tidak mengenal istilah demokrasi. Karena demokrasi ini berasal dari Barat atau Eropa yang masuk melalui peradaban Islam. Islam hanya mengenal istilah musyawarah sebagai fondasi utama dalam kehidupan sosial. Beranjak dari konsepsi musyawarah inilah Islam memperkenalkan gagasan demokrasi, yakni gagasan yang mengharuskan seluruh proses politik melandaskan diri pada partisipasi, kebebasan, dan persamaan. Dan dalam Al-Qur'an pun banyak ayat yang menjelaskan tentang musyawarah salah satunya dalam (Q.S. Asy-syura [42]: 38), dan (Q.S. Al-Hujuraat [49]: 13). Sehinggga kita dapat membedakan bahwa Islam dan demokrasi adalah dua sistem politik berbeda. Islam berbeda dengan demokrasi apa bila demokrasi didefinisikan secara prosedural seperti dipahami dan dipraktikan di negara-negara barat. Islam 
adalah sistem nilai yang membenarkan dan mendukung sistem politik demokrasi seperti yang dipraktikan di negara-negara maju.

Pendidikan demokratis dalam perspektif Islam adalah dijiwai oleh prinsip demokrasi dalam Islam, atau dengan kata lain demokrasi pendidikan Islam merupakan implementasi prinsip demokrasi Islam terhadap pendidikan Islam yaitu: Adanya kebebasan bagi pendidik dan peserta didik, yang mana kebebasan di sini meliputi: kebebasan berkarya, kebebasan mengembangkan potensi dan kebebasan berpendapat. Persamaan terhadap peserta didik dalam pendidikan Islam. Karena, Islam memberikan kesempatan yang sama bagi semua peserta didik untuk mendapatkan pendidikan atau belaja. Penghormatan akan martabat individu dalam pendidikan Islam.

Demokrasi sebagai penghormatan akan martabat orang lain, maksudnya ialah seseorang akan memperlakukan orang lain sebagaimana dirinya sendiri. sehingga dapat tercipta manusia atau pun masyarakat yang bertanggung jawab, bermartabat dan berakhlak mulia.

\section{DAFTAR PUSTAKA}

Daulay, H. P. (2014). Pendidikan Islam dalam Perspektif Islam. Jakarta: Kencana Prenadamedia Group.

Ilyas, Y. (2012). Kuliah Akhlaq. Yogyakarta: Lembaga Pengkajian dan Pengamalan Islam (LPPI).

Maarif, A. S. (2015). Islam dan Bingkai KeIndonesiaan dan Kemanusiaan: Sebuah Refleksi Sejarah. Bandung: PT Mizan Pustaka.

Musa, A. M. (2014). Membumingkan Islam Nusantara: Respon Islam terbadap Isu-isu Aktual. Jakarta: PT Serambi Ilmu Semesta.

Ramayulis. (2013). Ilmu Pendidikan Islam. Jakarta: Kalam Mulia.

Samudin, R. (2013). Fiqih Demokrasi:

\section{Menguak Kekeliruan Haramnya Umat Terlibat Pemilu dan Politik. Jakarta: Gozian Press.}

Tilaar, H. A. . (2012). Standarisasi Pendidikan Nasional: Suatu Tinjauan Kritis. Jakarta: Rineka Cipta.

Tirtarahardja, U., \& Sulo, L. (2008). Pengantar Pendidikan. Rineka Cipta.

Ubaedillah, A., \& Rozak, A. (2014). Pendidikan Kewarga Negaraan Civic Education Pancasila, Demokrasi, Ham, dan Masyarakat Madani. Jakarta: Kencana Prenadamedia Group.

Yasmadi. (2002). Modernisasi Pesantren Keritik Nurcholish Majid Terbadap Pendidikan Islam Tradisional. Jakarta: Ciputat Press. 